\title{
OBSERVATIONS ON CHYTRIDIACEOUS PARASITES OF PHANEROGAMS VII. A PHYSODERMA ON LYCOPUS AMERICANUS ${ }^{1}$
}

\section{Frederick K. Sparrow}

IN THE COURSE of routine collections of fungi, made during the summer of 1956 in northern Michigan, a species of Physoderma was found on Lycopus americanus. Since no species of this fungus genus have been described as attacking this host, a brief account of the main features of structure, reproduction and life history of the parasite seemed of interest.

The fungus remained subepidermal and induced on the host stem somewhat ellipsoidal, slightly raised pinkish or pale-brown pustules which were distinct or more or less confluent. They were up to $1.5 \mathrm{~mm}$. long by $0.5 \mathrm{~mm}$. wide and were primarily on the fifth and sixth internodes of the stem. These internodes were probably in the bud at the time of infection. It is possible, however, that the apical meristem was not infected; at least internodes above the sixth rarely harbored the fungus. Very heavy infections produced a marked swelling and dark purplish discoloration of the internode for a distance of $1.0 \mathrm{~cm}$. or more. Less often, the leaves were infected, again, primarily those at the fifth and sixth nodes. Here, the pustules were much smaller than those on the stem and were blackishbrown. They were more commonly found on the petiole than on the lamina. In the latter region they were either scattered over the lamina or aggregated near the leaf apex. The precise reasons for the striking localization of the infection must await further study. Quite obviously, a relationship exists between water level, time of germination of the overwintered resting spores, time of infection and stage of growth of the host.

It will be recalled that species of Physoderma have two very distinct phases in their life history. The well-known endobiotic one consisting of an extensive much-branched strongly polycentric rhizoidal system bears septate turbinate cells and, at maturity, numerous disproportionately large, thick-walled, amber or brown resting spores. In certain species (as $P$. menyanthis), the latter assume somewhat the shape of their confining host cell, or in others (as P. maydis) lie loosely in the host cells and are somewhat hemispherical in outline with a more or less flattened face. This phase induces the formation of dark-colored pustules, streaks, galls etc. on the host. The so-called "ephemeral sporangial phase" on the other hand, is invisible macroscopically. It consists of an epibiotic, typically chytridiaceous zoosporangium-

${ }^{1}$ Received for publication March 25, 1957.

Contribution No. 1069, Botany Department, University of Michigan and from the Biological Station.

Research supported by a grant from the National Science Foundation. like structure and an endobiotic system of short bushy rhizoids which occupies only a single cell.

Endobiotic stage.-No special features characterize the endobiotic phase of the fungus. The host epidermis, sclerified tissue and pith were not attacked, in contrast to the collenchyma, cortex, and phloem. Epidermal cells covering the gall area are stretched and noticeably more elongated than normal tissue. Underlying cortex cells, which average about $17 \times 23 \mu$ when uninfected, may attain when parasitized an average size (in cross section) of 38 $\times 41 \mu$. Similarly, phloem cells which may normally (in cross section) average $8 \times 12 \mu$, when infected average $22 \times 27 \mu$. The invaded host cells bear within them the usual complex of delicate branched rhizoids, usually once- or twice-septate turbinate organs, and resting spores. The latter are ellipsoidal, brownish, $16.5-27 \times 13.5-24 \mu$ (av. $21.6 \times 18.0 \mu)$, with a well-defined, relatively thin, one-layered wall. At maturity they are scattered loosely in the cells and appear to be without pits or antler-like outgrowths; the latter are, however, found on very young spores. In optical section (fig. 1) the flattened face shows distinct evidences of a broad operculum whereas in peripheral view (fig. 2) a line of dehiscence is distinctly visible as are uniform-sized globules and a large central vacuole in the contents.

Germination of resting spores.-The dried resting spores, which had been maintained at $8^{\circ} \mathrm{C}$. since their collection two months previously, were pretreated with several organic wetting agents as described by Elliott (1949) in his study of spore germination in Myxomycetes. They were then incubated in petri dishes in norite-treated distilled water at several different temperatures. The most rapid and abundant germination took place at about $22^{\circ} \mathrm{C}$.

Eighteen hours after immersion the first changes were noted in the spores. There had evidently occurred a pronounced swelling of the contents; the outline of the central vacuole was irregular as was the size of the globules, and the operculum rather than being somewhat sunken (fig. 2) was slightly raised (fig. 3). Two hours later, the sporangium had started to protrude from the spore, the central vacuole had enlarged and the operculum was dehisced and separated completely from the resting spore wall and carried upwards (fig. 5), or merely pushed back (fig. 4). The operculum varies from being almost flat with a marginal flange to smoothly convex. Within the resting spore the contents lose the central vacuole and appear denser as do those of the sporangium (fig. 6). At this time, too, the first evidences of the apjcal discharge papilla on the 


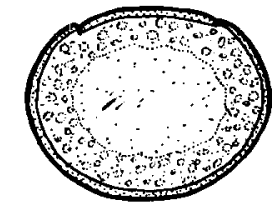

1
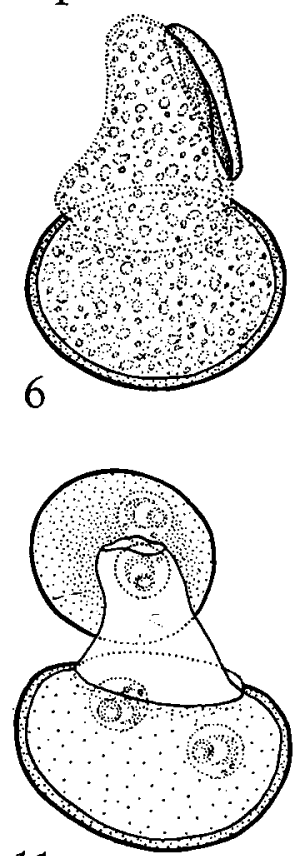

11

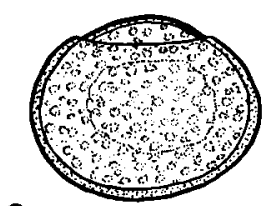

2

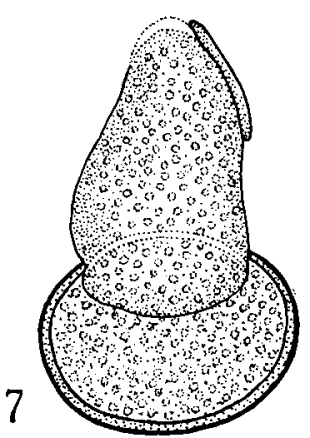

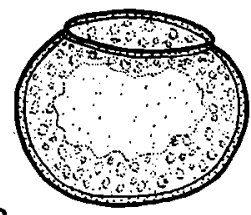

3

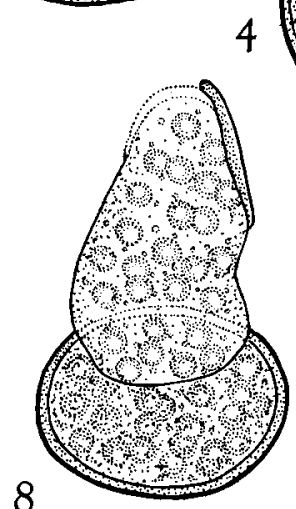

8

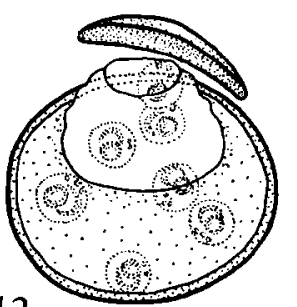

12
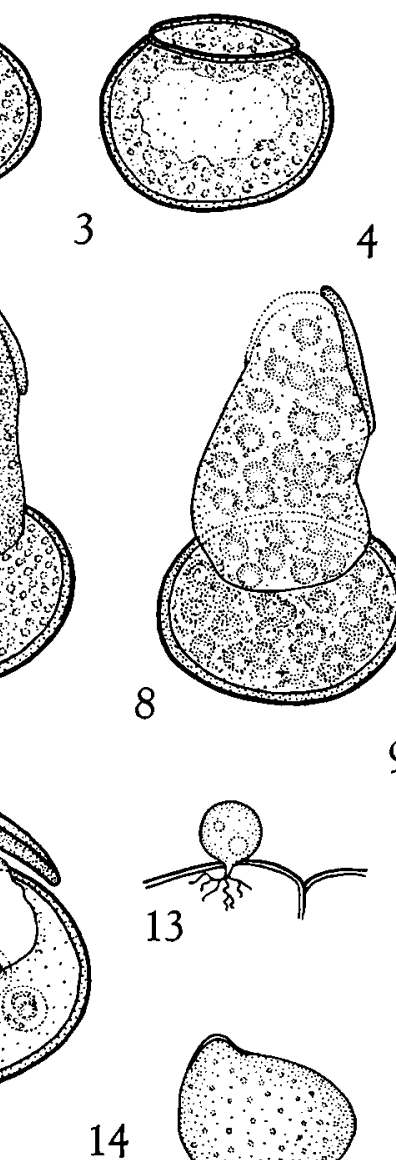
13
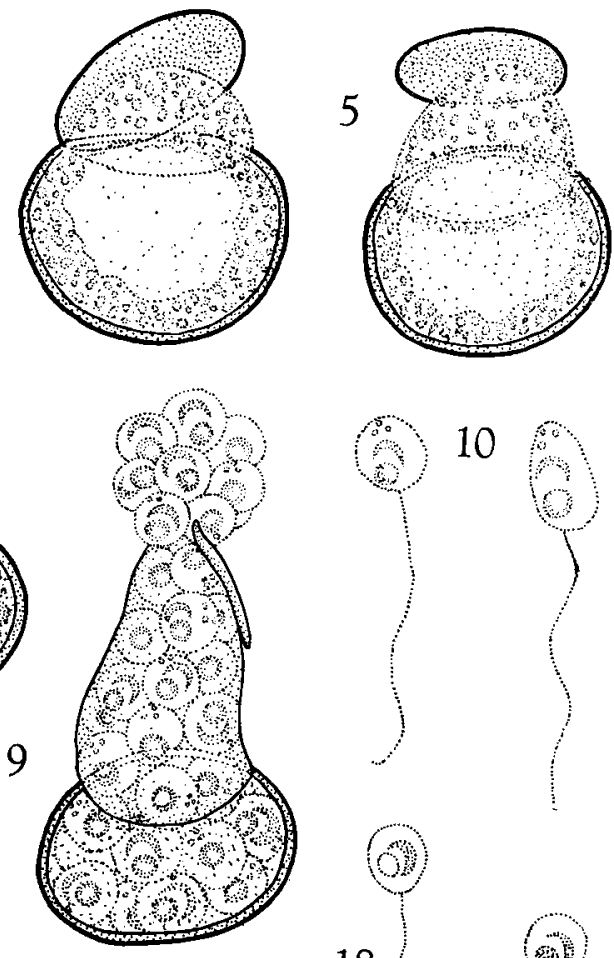

(6i)
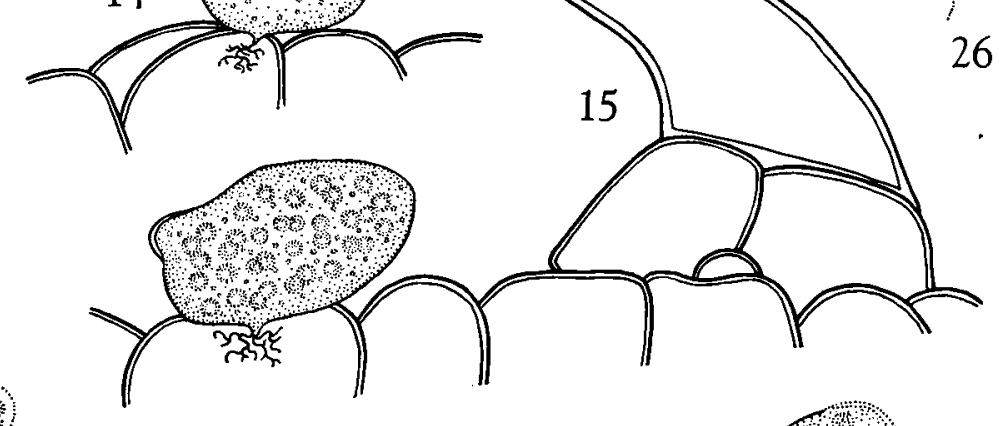

17

\%) धि
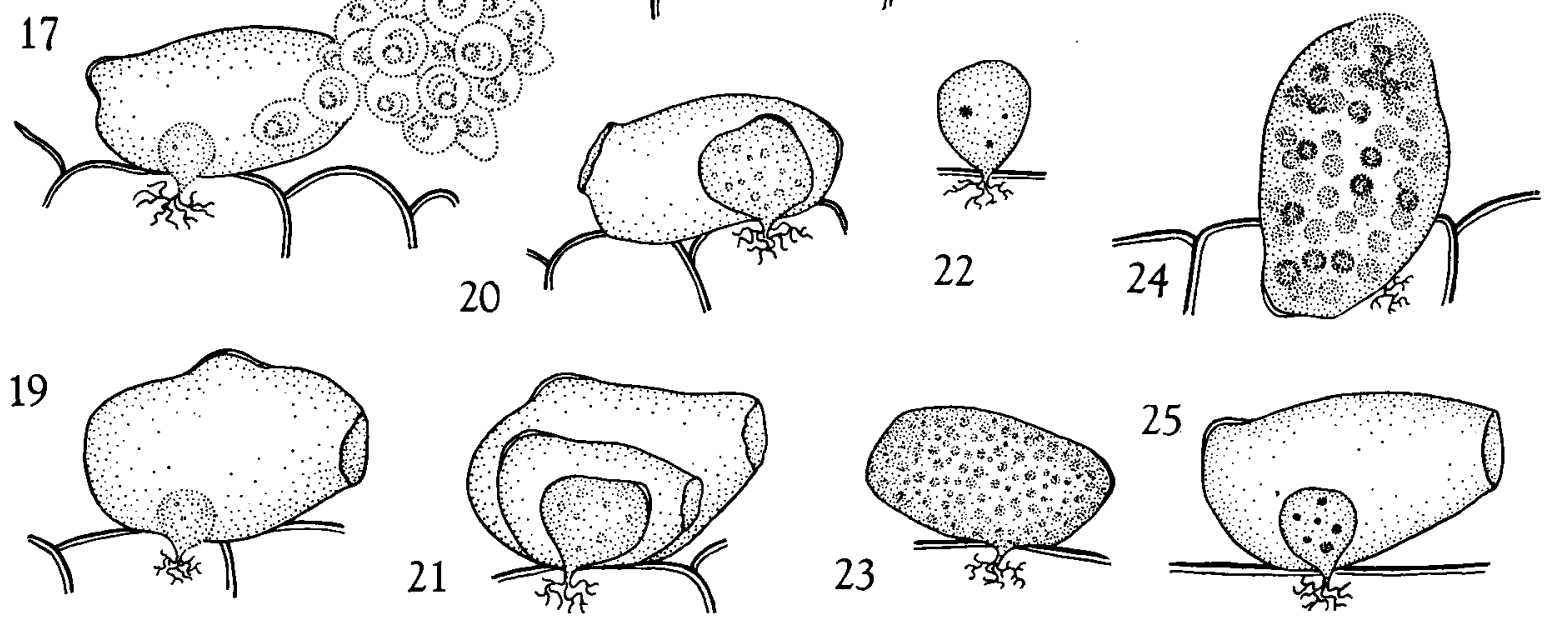
sporangium become visible. W'ithin 2-3 hr. after the broadly conical sporangium first protrudes from the resting spore it has achieved its maximum size $(25-30 \times 15 \mu)$. Subsequently, the apical papilla becomes more pronounced and the contents more uniform ( fig. 7). Unlike Physoderma pluriannulatum (Sparrow, 1957) there does not now ensue a stage in which rings of small globules are organized in the rudiments of the zoospores. Rather, the refractive bodies in the cytoplasm coalesce to form the like-sized large single globules of the zoospores and the small apical bodies (fig. 8).

The zoospores are cleaved out within the protruding sporangium and its concomitant resting spore. At maturity the broad apical papilla rapidly deliquesces and a few spores are extruded. These remain motionless at the apex for approximately a minute (fig. 9) before pulling away and swimming off. The remainder then assume motility and move individually to the outside. After discharge of all, or nearly all, the zoospores the wall of the sporangium shrinks and partially collapses (fig. $11,12)$. The zoospores at the moment of discharge are spherical but after assuming motility become ellipsoidal, pyriform or somewhat oblong. They are $5.5-6.8 \mu$, mostly $6.2 \mu$ when spherical, and $6.8-7.9 \mu \times 4-5 \mu$ when ovoid and bear an eccentric, colorless globule, a well-defined and clearly visible nuclear cap and $2-4$ minute apical granules (fig. 10). They are swift, even swimmers.

Ephemeral sporangial stage.-Empty ephemeral sporangia were found in the field in October on fragments of host epidermis covering infected areas. They were also formed in abundance on leaf petiole and lamina and on the stem, but not roots, three days after immersion in water in which zoospores from germinated resting spores were swimming. There was evidence, as in Physoderma menyanthis (Sparrow, 1946) that new sporangia were being formed by zoospores from the ephemeral sporangia. In very early stages of infection the encysted zoospore puts out a penetration tube at the tip of which a delicate bushy cluster of branched rhizoids was formed (fig. 13). The cyst enlarged unequally, and, as in all other instances thus far found in the ephemeral sporangia of Physoderma, a portion of it remained as a thicker-walled, arc-like lateral, or less often subapical, structure on the developing asymmetrical sporangium (fig. 14, 15). When mature, the sporangium was somewhat anatropous, its longer axis being tilted up to $60^{\circ}$ from the surface of the host. At the opposite end from that bearing the remnants of the zoospore cyst wall, a broad papilla slowly developed. The sporangial contents which bore at first many unlike-sized irregularly distributed globules, at maturity contained about 30 globules of uniform size, one destined for each zoospore.

Upon the deliquescence of the broad discharge papilla, the zoospores emerged in a cluster from which they soon escaped as they assumed individual flagellar activity. They were spherical at first (fig. 17-18), and 3.9-4.7 $\mu$ in diameter but became more narrowly ovoid when in motion. Internally, they bore an eccentric globule, a clearly visible nuclear cap, but no anterior granules (fig. 18). Internal proliferation of discharged ephemeral sporangia was frequent (fig. 19-21).

Evidences for possible sexuality.-Some years ago this writer (1940) postulated that these long. known ephemeral sporangia, of unknown significance in the life cycle, were gametangia and that their zoospores, markedly smaller than those from resting spores, were gametes. No positive proof of this has as yet appeared. Observations on the present species seem, however, to lend some support to this hypothesis.

Certain of the ephemeral sporangia formed on living Lycopus tissue differed from the majority in one significant respect, namely, their protoplasm was a faint orange and the globules of the mature zoospores were the same color (fig. 23-26). Furthermore, when both colorless and colored globuled forms were rapidly swimming in the medium, they sometimes appeared to be slightly unequal in size. Individual cases of fusion of colorless and colored globuled forms were observed but not in sufficient numbers to provide conclusive evidence of sexuality. These facts, of course, serve to recall the situation in Allomyces of the Blastocladiales, where fusion of anisogamous gametes, a smaller orangeglobuled male with a larger colorless female, has been long known, or in Blastocladiella variabilis, where colorless- and colored-globuled, like-sized gametes, fused.

It must be admitted, however, that differences in light intensities during growth might have caused

Fig. 1-26. Germination of the resting spores and formation of ephemeral sporangia in Physoderma lycopi, n.sp.Fig. 1. Section view of resting spore showing flattened side with lid and large central vacuole.-Fig. 2. Surface view of same.-Fig. 3-5. Stages in dehiscence of lid and protrusion of sporangium from body of resting spore.-Fig. 6-7. Changes in aspect of contents of sporangium and appearance of discharge papilla.-Fig. 8. Organization of globules of zoospores.-Fig. 9. Discharge of zoospores.-Fig. 10. Shapes assumed by zoospores from resting spores.-Fig. 1112. Discharged sporangia, a few zoospores remaining.-Fig. 13. Very young stage in development of ephemeral sporangium.-Fig. 14-16. Ephemeral colorless sporangia in varying stages of development, showing thick-walled portion of unexpanded zoospore cyst and discharge papilla.-Fig. 17. Discharge of colorless zoospores.-Fig. 18. Single zoospore from ephemeral sporangium.-Fig. 19-21. Internally proliferous ephemeral sporangia.-Fig. 22-25. Various stages in development of ephemeral sporangia with orange-colored globules.-Fig. 26. Zoospore with colored globule. All figures drawn from living material with the aid of the camera-lucida. $\times 1160$. 
the observed coloration although all developing sporangia were subject to the same light conditions, and that spores from internally proliferated sporangia may have been smaller than those from primary sporangia. The occurrence of sexuality here is still inconclusive. Further, Clinton (1902) called attention to the fact that in Physoderma maculare the zoospores from ephemeral sporangia sometimes had oil drops of a "sickly reddish-yellow color" and in Physoderma pulposum they were uniformly bright golden.

Host specificity.-Around the margin of the lake where the fungus was discovered, numerous stands of Lycopus americanus and Mentha arvensis occurred side by side or were only separated by short distances. Furthermore, both species were undoubtedly in standing lake water in springtime when the lake level was higher than at the time of collection. No infection was found on Mentha arvensis. In the summer of 1956, therefore, it can be said that at this particular site Physoderma infection was confined to only one species of the family growing there, namely Lycopus americanus.

Confirmation of this host specificity is given by the experiments to induce the formation of ephemeral sporangia described above. Mentha plants similarly exposed to water swarming with zoospores from lhysoderma resting spores were free of ephemeral sporangia whereas those of Lycopus, as indicated, bore great numbers of them.

Host specificity of the Lycopus parasite seems further borne out by the results of greenhouse inoculations of plants of Lycopus americanus and Mentha arvensis from the same site. Zoospores from germinated resting spores were applied to parts of prospective host plants either by pads of cotton soaked in a suspension of zoospores in water or by bending the host down into small dishes of such a suspension. The cotton pads were left on for nine days whereas the plants immersed in water with zoospores were left in that position for five days. Fourteen days later definite evidences of infection were found on both sets of Lycopus plants. No infections could be detected on Mentha. Forty. five days after the host was first exposed to the fungus, brown-walled resting spores of the Physoderma were found. Seasonal scarcity of host material and Physoderma resting spores precluded attempting extensive cross-inoculation work at this time. What has been done, however, bears out the field observations that the present strain of Physoderma on Lycopus americanus will not infect the strain of Mentha arvensis growing at the same site.

No great differences in size of the resting spores separate Physoderma menthae Schroeter from the fungus on Lycopus, those of the former being $22-33 \mu$ in diameter as compared with $18 \times$ $21 \mu$. However, according to Jones and Dreschler (1920), P. menthae resting spores have a zone of pits on them and hence, probably bore branched, antler-like haustoria. No pits have been found in the present species on mature resting structures. As indicated earlier, antler-like projections are present on the rudiments of the spores.

The Physoderma on Lycopus is considered for the present a species distinct from $P$. menthae. This decision is supported by the fact that the fungus is neither transferable to Mentha nor found in the field on this host and has structural features (ephemeral sporangia of two kinds, etc.) not reported for $P$. menthae. Further studies of its host range, development of the endobiotic system, etc. will be reported in later papers.

Physoderma lycopi n. sp. ${ }^{2}$-Epibiotic sporangium ovoid or pyriform, somewhat anatropous. its long axis tilted as much as $45-60^{\circ}$ from the host surface, with one end usually terminating in the thick-walled, unexpanded portion of the zoospore cyst, the other in a broad discharge papilla. $23-26 \times 12-15 \mu$, smaller ones formed by internal proliferation; rhizoidal system exceedingly delicate, composed of short bushy rhizoids; zoospores globose, more elongate when in motion; $3.9-4.7 \mu$ in diameter sometimes smaller, of two types, with a colorless, or with an orange-colored globule, a distinct nuclear cap always visible; endobiotic system extensive, much branched, delicate, not strap-like. with numerous once- or twice-septate turbinate cells and brown, thick-walled somewhat ellipsoidal resting spores flattened on one surface, $16.5-27 \times$ $13.5-24 \mu$, without pits or branched processes at maturity, upon germination dehiscing by a lid from the flattened side, the subsequently developed sporangium broadly conical, its zoospores spherical and $5.5-6.8 \mu$ in diameter or ovoid and $6.8-7.9 \times$ $4-5 \mu$, bearing an eccentric colorless globule; $a$

${ }^{2}$ Physoderma lycopi $n$. sp. Sporangium epibioticum primarium ovoideum vel pyriforme, paululo anatropum, interdum $45^{\circ}-60^{\circ}$ ex Lycopi epidermate divergens, lateraliter sed excentrice et obliquiter affixum apicibus ambobus liberis, extremitate breviori in partem inexpansum cistellae crassivallatae terminanti; extremitate breviori in papillam latam deliquescentem terminanti. Sporangia secondaria proliferatione interna formata. Systema rhizoideum tenuissimum breviter ramosum. Zoosporae sphaericae, plerumque $3.9-4.7 \mu$ diametro (interdum parviores), motentes subelongatae, aliae pellucidae aliae globulo aurantiaco praeditae, operculo distincto. Systema endobioticum extense ramosum tenuissimum haud apparenter tubulosum; cellulis turbinatis bruneis, uniseptatis vel biseptatis; sporis perdurantibus crassivallatis ellipsoideis unilateraliter applanatis, $16.5-27 \mu$ longis, $13.5-24 \mu$ latis, absque excavationibus, interdum processionibus ramosis praeditis, germinatione ab operculo in latere applanato dehiscentibus. Sporangium late conicum, zoosporis sphaericis, 5.5-6.8 $\mu$ diametro, vel ovoideis, $6.8-7.9 \mu$ longis, $4-5 \mu$ latis, globulum excentricum pellucidum, cupulam nuclei, et $2-4$ granulos minutos apicalis includentibus; flagellum longum, postice ferentibus.

Parasiticum in caulibus Lycopi americani, intumescentias formans, etiamque raro in foliis; in vicinitate "Douglas Lake, Cheboygan County, Michigan." (Prepared by H. H. Bartlett.) 
well-defined nuclear cap, 2-4 minute apical granules and a long posterior flagellum.

Parasitic on Lycopus americanus vicinity of Douglas Lake, Cheboygan Co., Mich., July 7, 1956.

\section{SUMMARY}

A species of Physoderma which causes pronounced hypertrophy has been found on Lycopus umericanus in northern Michigan. It is characterized primarily by having epibiotic sporangia of two types, one producing colorless zoospores, the other zoospores with orange-colored globules. The fungus on the basis of field observations and preliminary cross-inoculation experiments is seemingly confined to Lycopus americanus.

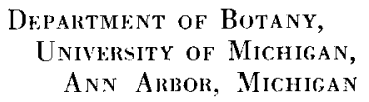

\section{LITERATURE CITED}

Clinton, G. P. 1902. Cladochytrium alismatis. Bot. Gaz. 33: 49-61.

ElliotT, E. W. 1949. The swarm-cells of myxomycetes. Mycologia 41 : 141-170.

Jones, F. R., and C. Drechsler. 1920. Crownwart of alfalfa caused by Urophlyctis alfallae. Jour. Agric. Res. 20: 295-323.

Sparrow, F. K. 1940. Chytridiaceous fungi in relation to disease in flowering plants, with special reference to Physoderma. viii +883 pp. In Abstracts of Comm., III International Congress of Microbiology. New York.

1946. Observations on chytridiaceous parasites of phanerogams. I. Physoderma menyanthis de Bary. Amer. Jour. Bot. 33: 112-118.

- 1957. Observations on chytridiaceous parasites of phanerogams. VI. Resting spore germination in Physoderma (Urophlyctis) pluriannulatum. Mycologia (in press).

\section{STUDIES ON THE DEVELOPMENT OF EXCISED LEAVES IN STERILE CULTURE ${ }^{1}$}

\section{Taylor A. Steeves ${ }^{2}$ and I. M. Sussex}

The initiation and development of leaves have long been processes of fundamental interest to students of morphogenesis in the vascular plants. The leaf has its inception in a portion of the apical meristem which is seemingly equivalent to adjacent areas. Yet in its rapid but limited growth and its development into a typically dorsiventral organ, it differs strikingly from the whole meristem which is indeterminate and which produces the radially symmetrical shoot system. Much has been done to explore, by experimental techniques, the factors underlying the appearance of leaf primordia in regular sequence and in definite positions at the margins of the shoot apical meristem and their subsequent development into organs which are typically both dorsiventral in their symmetry and determinate in their growth (Wetmore and Wardlaw. 1951).

Yet it is evident that the fundamental mechanisms underlying leaf development are not clearly understood. Observations upon intact plants and even surgical experiments have not, for example, shown whether the complex pattern of leaf development, once established, is autonomous within the leaf it-

${ }^{1}$ Received for publication February 25, 1957.

This work was supported in part by a grant to Professor R. H. Wetmore and the senior author from the American Cancer Society, Inc., upon the recommendation of the Committee on Growth. The authors express their appreciation to Professor R. H. Wetmore for his helpful guidance and generous assistance during the course of these investigations, to Professor Ernest M. Gifford, Jr. and Dr. Carl R. Partanen for their reading of the manuscript, and to Mrs. Marcaret $W$. Steeves for her aid in the preparation of the manuscript.

"Junior Fellow of the Society of Fellows, Harvard University, during part of these investigations. self, or whether it is dependent upon a constant relationship to the whole organism.

The use of sterile culture techniques has greatly enhanced the study of developmental and physiological processes in shoots (Loo, 1945, 1946 a, b; Ball, 1946; Wetmore and Morel, 1949, Wetmore, 1950) and roots (White, 1934) and even in fruits (Nitsch, 1951), which are determinate organs. It seemed possible, therefore, that these techniques might be applied with advantage to investigations of leaf morphogenesis. In an earlier paper (Sussex and Steeves, 1953) it was shown that excised leaves of the fern Osmunda cinnamomea L. could be grown to maturity in sterile culture. The present paper is a more extensive report of these experiments togcther with additional observations. Fern leaves were chosen for the initial investigations in part because their prolonged but limited terminal growth scemed to provide favorable material for such a study, and in part because there was reason to believe that their cultural requirements might be relatively simple (Wetmore, 1954). The fern Osmunda cinnamomea was chosen for this study because considerable morphological and anatomical information was already available for this species (Steeves and Wetmore, 1953).

MORPHOLOGY AND LEAF DEVELOPMENT OF OSMUNDA CINNAMOMEA.-Osmunda cinnamomea is characterized by a compact and largely subterranean apical bud surrounded by the expanded fronds of the current season. At the time of its most complete development, during the period of dormancy, the bud contains a reservoir of leaves, usually between sixty and eighty, of which approxi- 